\title{
Optimised Fractionation of Brewer's Spent Grain for a Biorefinery Producing Sugars, Oligosaccharides, and Bioethanol
}

\author{
Soma Bedő, Margaréta Rozbach, Leonóra Nagy, Anikó Fehér and Csaba Fehér *
}

Citation: Bedő, S.; Rozbach, M.;

Nagy, L.; Fehér, A.; Fehér, C.

Optimised Fractionation of Brewer's Spent Grain for a Biorefinery Producing Sugars, Oligosaccharides, and Bioethanol. Processes 2021, 9, 366. https://doi.org/10.3390/pr9020366

Academic Editors: Antonio D. Moreno, Fabrizio Scala and Paloma Manzanares

Received: 23 December 2020

Accepted: 5 February 2021

Published: 16 February 2021

Publisher's Note: MDPI stays neutral with regard to jurisdictional claims in published maps and institutional affiliations.

Copyright: (c) 2021 by the authors. Licensee MDPI, Basel, Switzerland. This article is an open access article distributed under the terms and conditions of the Creative Commons Attribution (CC BY) license (https:// creativecommons.org/licenses/by/ $4.0 /)$
Biorefinery Research Group, Department of Applied Biotechnology and Food Science, Budapest University of Technology and Economics, 1111 Budapest, Hungary; bedo.soma@vbk.bme.hu (S.B.); rozbachgreti@gmail.com (M.R.); nleonora96@gmail.com (L.N.); feher.aniko@mail.bme.hu (A.F.)

* Correspondence: feher.csaba@vbk.bme.hu

Abstract: Brewer's spent grain (BSG) is the main by-product of the beer brewing process. It has a huge potential as a feedstock for bio-based manufacturing processes to produce high-value bioproducts, biofuels, and platform chemicals. For the valorisation of BSG in a biorefinery process, efficient fractionation and bio-conversion processes are required. The aim of our study was to develop a novel fractionation of BSG for the production of arabinose, arabino-xylooligomers, xylose, and bioethanol. A fractionation process including two-step acidic and enzymatic hydrolysis steps was investigated and optimised by a response surface methodology and a desirability function approach to fractionate the carbohydrate content of BSG. In the first acidic hydrolysis, high arabinose yield (76\%) was achieved under the optimised conditions $\left(90{ }^{\circ} \mathrm{C}, 1.85 \mathrm{w} / \mathrm{w} \%\right.$ sulphuric acid, $\left.19.5 \mathrm{~min}\right)$ and an arabinose- and arabino-xylooligomer-rich supernatant was obtained. In the second acidic hydrolysis, the remaining xylan was solubilised $(90 \%$ xylose yield) resulting in a xylose-rich hydrolysate. The last, enzymatic hydrolysis step resulted in a glucose-rich supernatant $(46 \mathrm{~g} / \mathrm{L})$ under optimised conditions (15 w/w\% solids loading, $0.04 \mathrm{~g} / \mathrm{g}$ enzyme dosage). The glucose-rich fraction was successfully used for bioethanol production (72\% ethanol yield by commercial baker's yeast). The developed and optimised process offers an efficient way for the value-added utilisation of BSG. Based on the validated models, the amounts of the produced sugars, the composition of the sugar streams and solubilised oligo-saccharides are predictable and variable by changing the reaction conditions of the process.

Keywords: biorefinery; response surface methodology; dilute acid hydrolysis; enzymatic hydrolysis; lignocellulosic residue; arabino-xylooligosaccharide; arabinose; xylose; D-function approach; Saccharomyces cerevisiae

\section{Introduction}

Brewer's spent grain (BSG) is a by-product of the brewing industry. It is the solid residue of the mashing process, which contributes to $85 \%$ of the total by-product of the brewing [1]. BSG is a cheap raw material produced all year round in large quantities from small breweries to large ones [2]. Around 34 million tonnes of BSG are generated annually, which means approximately 8.5 million tonnes of dry BSG [3]. BSG mainly consists of lignocellulose (cellulose, hemicellulose, and lignin), proteins, and minerals [1]. Due to its high moisture content, the transport and long-term storage of BSG are difficult [4]. Thus, nowadays it is mainly used for feeding cattle in local farms [5].

BSG can be used for energy purposes to produce electricity by combustion [6]. However, BSG needs to be dried in advance of direct combustion and large amount of harmful NOx is released during the process [6,7], making it less advantageous. Another option to produce energy from BSG is the production and subsequent combustion of biogas derived from the anaerobic digestion of that [8].

BSG can be widely used in the food industry. It can increase the nutrient content of various bakery products [9]. However, white flour can only be partially replaced by BSG 
powder to avoid an unpleasant taste and brown colour of the obtained products [10]. Due to the high content of essential amino acids in BSG, the protein composition of different foods and feeds can also be improved [11,12]. BSG has antioxidant properties due to their phenolic components (mainly ferulic and p-coumaric acids) [13], thus it can be used in functional foods as well.

Recently, many studies have revealed the potential of BSG as a raw material for biotechnological conversion processes to produce value-added bio-products, platform chemicals, or biofuels. BSG can serve as a protein-rich raw material in solid state fermentation processes, mainly aimed at the production of enzymes such as proteases, xylanases, and cellulases [14-16]. BSG contains a high amount of hemicellulose, which is composed of arabinoxylan polymers [17]. The xylose content of that can be released in monomeric form by using different (acidic, enzymatic) hydrolysis techniques [18,19]. BSG hydrolysates containing a high concentration of xylose are considered promising fermentation media for the microbial production of xylitol, which is a high-value bio-product with several possible applications [18]. Moreover, various arabino-xylooligosaccharides (AXOS) can also be prepared from BSG by the incomplete hydrolysis of its solubilised hemicellulosic polymers [20]. AXOS are promising substances in functional foods due to their potential prebiotic properties [21]. Second-generation bioethanol can be produced from the glucan fraction of BSG [22]. Bioethanol production from BSG does not result in increasing food prices, deforestation, or reduction of arable land [23], making it an advantageous and possibly sustainable process for biofuel production.

Valorising BSG in a biorefinery process could allow the combined production of a widerange of bio-chemicals, biofuels, and platform molecules. As an example, Davila et al. [24] proposed a biorefinery process producing ethanol, xylitol, and polyhydroxybutyrate from BSG. However, for the successful conversion of lignocellulosic biomass into a spectrum of value-added products, an efficient fractionation process is required to separate the main constituents of the raw material [25]. Pre-treatment methods, such as liquid hot water/autohydrolysis [26,27], microwave-assisted hydrothermal [28], acidic [29] alkali [30], nonthermal plasma [31], ultrasonic-assisted [32], steam explosion [33] enzymatic (proteases, glycoside hydrolases, laccases) [34,35], microbial [21], and different combinations of those treatments $[36,37]$ have been extensively studied over the past years in order to separate the protein, lignin, and different carbohydrate fractions from BSG. However, most of them had the main focus of separating one selected component or simply enhancing a subsequent enzymatic hydrolysis step. For the complex valorisation of BSG in a biorefinery process, different pre-treatments must be merged into a sequential fractionation process, which allows the separation of many different components. The most favourable fractionation of BSG, containing different pre-treatments, has to be developed according to the main purpose and products of the biorefinery process [38]. For example, separating high value components in advance of bioethanol production from BSG would be extremely important from an economic point of view, since many studies have pointed out that in most of the cases the lignocellulosic bioethanol production can only be economically viable as part of a biorefinery process producing other, high value bio-products [39-41].

The main goal of this study was to invent a complex and responsive fractionation process that could enhance the viability of bioethanol production from BSG by allowing the prior and selective fractionation of different high-value hemicellulosic components, and thus embed bioethanol production into a biorefinery process. Hence, our aim was to develop and optimise a novel fractionation method consisting of different hydrolytic process steps in order to separately obtain arabinose-rich and xylose-rich hydrolysates from BSG, beside a glucose-rich hydrolysate that is applicable for efficient bioethanol production.

\section{Materials and Methods}

\subsection{Microorganisms and Lignocellulosic Raw Material}

Commercial baker's yeast (Saccharomyces cerevisiae) was purchased from Lesaffre Hungary Ltd. (Budafok, Hungary). Brewer's spent grain (BSG) was kindly donated 
from Dreher Co. Ltd. (Budapest, Hungary). It was dried at $40{ }^{\circ} \mathrm{C}$ and then stored at room temperature.

\subsection{Compositional Analysis}

The dry content of BSG was measured by rapid moisture analyser (Precisa XM 60). The glucan, xylan, arabinan and Klason-lignin contents were analysed by using the NREL (National Renewable Energy Laboratory) method [42] with minor modifications detailed by Fehér et al. [43]. The starch content was determined according to the method described by Bedő et.al [44]. The crude protein content was determined by Dumas method [45]. The inorganic compounds were determined gravimetrically after treated at $550{ }^{\circ} \mathrm{C}$ for $6 \mathrm{~h}$ in muffle furnace equipped with a ramping program [46]. The compositional analyses were carried out in triplicates.

\subsection{First Acidic Hydrolysis}

The first acidic hydrolysis was performed on a suspension of BSG and dilute sulphuric acid in $25 \mathrm{~g}$ reaction mixture in $100 \mathrm{~mL}$ glass flasks. The reaction time (10, 30, $50 \mathrm{~min})$ and the sulphuric acid concentration $(0.5,1.25,2.0 w / w \%)$ were varied according to a full factorial experimental design. The range of the reaction time and sulphuric acid concentration were determined according to preliminary tests and previous studies $[43,44]$. Hydrolyses occurred at $90{ }^{\circ} \mathrm{C}$ reaction temperature in water bath without agitation. A warm-up period of $10 \mathrm{~min}$ was applied in all cases before starting to measure the reaction time in order to reach the reaction temperature. The dry matter content of the reaction mixtures was $10 w / w \%$. After the reaction, the hydrolysates were cooled down in a coldwater bath for $5 \mathrm{~min}$ and the mixtures were filtered through a nylon filter with $50 \mu \mathrm{m}$ pore size. The supernatants were analysed for solubilised sugars. The experiment was repeated at optimum conditions: $1.85 w / w \%$ sulphuric acid concentration and 19.5 min reaction time. In this case, the solid residue was neutralized by distilled water, dried at $40^{\circ} \mathrm{C}$, and stored at room temperature until the next hydrolysis step.

\subsection{Second Acidic Hydrolysis}

In the second acidic hydrolysis, the solid residue of the optimised first acidic hydrolysis was treated in autoclave at $121^{\circ} \mathrm{C}$ for $30 \mathrm{~min}$ without agitation in a reaction mixture containing $1 w / w \%$ sulphuric acid and $10 w / w \%$ dry matter, in order to completely solubilise the hemicellulose fraction. The reaction conditions were selected based on previous study [44] and preliminary tests. After the treatment, the solid residue was separated by a nylon filter with $50 \mu \mathrm{m}$ pore size and washed with distilled water to neutralise. It was dried at $40{ }^{\circ} \mathrm{C}$ and then stored at room temperature until further experiments.

\subsection{Enzymatic Hydrolysis}

Enzymatic hydrolysis was carried out on the solid residue of the second acidic hydrolysis by Cellic ${ }^{\circledR}$ CTec 3, which was kindly donated from Novozymes A/S (Copenhagen, Denmark). The total weight of the reaction mixture was $15 \mathrm{~g}$. The enzyme dosage (0.01, 0.03, $0.05 \mathrm{~g}$ enzyme mixture/g dry matter, referred to as $\mathrm{g} / \mathrm{g} \mathrm{DM})$ and the solids loading (5, $10,15 w / w \%$ on dry basis) were varied according to a full factorial experimental design. The enzymatic hydrolyses were performed in acetate buffer $(0.1 \mathrm{M}, \mathrm{pH}=5)$ at $50{ }^{\circ} \mathrm{C}$ for $72 \mathrm{~h}$ by shaking at $125 \mathrm{rpm}$. The hydrolysis was repeated in duplicates under optimal conditions: $15 w / w \%$ solids loading and $0.04 \mathrm{~g} / \mathrm{g}$ DM enzyme dosage. The glucose content of the liquid phase was analysed by high-performance liquid chromatography.

\subsection{Inoculum Preparation}

To obtain an active culture of baker's yeast for the inoculation of ethanol fermentation experiments, Saccharomyces cerevisiae was propagated in a medium containing $50 \mathrm{~g} / \mathrm{L}$ glucose, $0.3 \mathrm{~g} / \mathrm{L}$ magnesium sulphate heptahydrate $\left(\mathrm{MgSO}_{4} \cdot 7 \mathrm{H}_{2} \mathrm{O}\right), 2 \mathrm{~g} / \mathrm{L}$ ammonium 
chloride $\left(\mathrm{NH}_{4} \mathrm{Cl}\right)$, and $1 \mathrm{~g} / \mathrm{L}$ dipotassium hydrogenphosphate $\left(\mathrm{K}_{2} \mathrm{HPO}_{4}\right)$. The inoculum was cultured at $30^{\circ} \mathrm{C}$ and $220 \mathrm{rpm}$ shaking for $24 \mathrm{~h}$.

\subsection{Ethanol Fermentation}

Ethanol fermentation was performed on the hydrolysate obtained from the optimised enzymatic hydrolysis, by Saccharomyces cerevisiae at $30^{\circ} \mathrm{C}, 150 \mathrm{rpm}$ shaking for $72 \mathrm{~h}$. The initial cell concentration was $5 \mathrm{~g} / \mathrm{L}$. The working volume was $5 \mathrm{~mL}$ in $15 \mathrm{~mL}$-glass flasks. After the inoculation, the flasks were purged by nitrogen in order to provide anaerobic conditions. The fermentation was carried out in duplicates and monitored by daily sampling.

\subsection{Analytical Methods}

2.8.1. Determination of Sugars, Ethanol and Inhibitor Compounds

Concentrations of glucose, xylose, arabinose, ethanol, acetic acid, formic acid, 5hydroxymethyl-furfural (HMF), and furfural were quantified by high-performance liquid chromatography (HPLC) with refractive index detection. Separation was achieved on BioRad (Hercules, CA, USA) Aminex HPX-87H $(300 \times 7.8 \mathrm{~mm})$ column equipped with Micro-Guard Cation H+ Refill Cartridge $(30 \times 4.6 \mathrm{~mm})$ guard column, heated at $65^{\circ} \mathrm{C}$, using $5 \mathrm{mmol} / \mathrm{L}$ sulphuric acid at a flow rate of $0.5 \mathrm{~mL} / \mathrm{min}$ [43]. Xylooligosaccharides were analysed by thin layer chromatography (TLC) according to the method detailed by Ontañon et al. [47]. Total phenol contents were determined by the Folin-Ciocalteu method according to Guo et al. [48].

\subsubsection{Determination of Total Sugar Content}

Liquid samples were mixed with $8 w / w \%$ sulphuric acid at a volume ratio of 1:1, and treated in an autoclave $\left(121^{\circ} \mathrm{C} ; 1 \mathrm{bar}\right)$ for $20 \mathrm{~min}$ in order to decompose the solubilised oligosaccharides into monomers. Monosaccharides were then quantified by HPLC and the results were referred to as total amount of solubilised sugars. Hence, the amount of total sugars includes the amounts of solubilised monomers and oligomers together.

\subsubsection{Determination of Cell Concentration}

Cell concentration was analysed by measuring optical density at a wavelength of $600 \mathrm{~nm}$ (Ultrospec III spectrophotometer, Pharmacia LKB, Uppsala, Sweden). The cell concentration was calculated by using a calibration curve based on dry cell mass measurements.

\subsection{Calculation of Yields of Sugars, GOS and AXOS, A/X Ratio and Ethanol Yield}

Sugar yields of the hydrolytic process steps were expressed as a percentage of theoretical based on the composition of the starting material that is used in the given process step. Yields of monosaccharides (monomer yields of glucose, xylose, and arabinose), yields of total sugars (total yields of glucose xylose and arabinose), and yields of oligosaccharides (yields of gluco-oligosaccharide and arabino-xylooligosaccharide) were distinguished. The yields of gluco-oligosaccharide (GOS) and arabino-xylooligosaccharide (AXOS) were calculated by subtracting the monomer sugar yields from the total sugar yields. In the calculation of AXOS yield, the amounts of xylose and arabinose were summed up in both of the cases of total and monomer yields, since these sugars are present together as an arabinoxylan in BSG [20].

The $\mathrm{A} / \mathrm{X}$ ratio was calculated as the ratio of the amount of arabinose and xylose present in the AXOS fraction.

The ethanol yield was calculated by dividing the amount of produced ethanol by the theoretical maximum by assuming a complete stoichiometric conversion of the initial glucose concentration to ethanol, and it was expressed as a percentage of the theoretical. 


\subsection{Statistical Evaluation}

Response surface methodology (RSM) was used to optimise the solubilisation of arabinose during the first acidic hydrolysis. A $3^{2}$ full factorial experimental design was performed with 3 replicates at the centre point. The independent variables were the reaction time and the sulphuric acid concentration, which were set to be 10,30, and $50 \mathrm{~min}$ and $0.5,1.25$, and $2 w / w \%$, respectively. The effects of these variables on the response variables (monomer yields of glucose, xylose, and arabinose; total yields of glucose, xylose, and arabinose; yields of GOS and AXOS, A/X ratio) were investigated. A quadratic polynomial model (Equation (1)) was fitted to the measured values:

$$
Y=b_{0}+b_{1} X_{1}+b_{2} X_{2}+b_{12} X_{1} X_{2}+b_{11} X_{1}^{2}+b_{22} X_{2}^{2}
$$

where $Y$ is the dependent variable, $X_{1}$ and $X_{2}$ are the independent variables, $b_{0}$ is the intercept, $b_{1}, b_{2}$ are the linear terms, $b_{12}$ is the term of the interaction between the two independent variables, and $b_{11}$ and $b_{22}$ are the quadratic terms. The statistical evaluation was performed by StatisticaTM v.13 software (TIBCO Software, Palo Alto, Santa Clara, CA, USA). The adequacy of the models was tested by F-test ( $\alpha=0.05$ significance level). The models were reduced by the non-significant variables. The effect of the independent variables was also checked by Pareto chart. In the model equations of the first acidic hydrolysis (Equations (3)-(11)), the reaction time is referred to as T expressed in minutes, and the sulphuric acid concentration is referred to as $\mathrm{S}$ expressed in $w / w \%$.

Desirability function (D-function) approach was used to determine the optimum conditions regarding total arabinose and total xylose yields simultaneously. The response variables $\left(Y_{i}\right)$ were transformed into desirability values $\left(d_{j}\right)$, where $d_{i}$ was a value from 0 to 1 depending on the given settings, while $j(1,2, \ldots, n)$ represented the number of the individual desirability functions. The D-function was calculated by the geometric means of the individual desirability functions (Equation (2)):

$$
D=\sqrt[n]{d_{1} \times d_{2} \times \ldots \times d_{n}}
$$

The settings of the desired intervals for total arabinose yield and total xylose yield were the followings: $50 \% \leq$ total arabinose yield $\leq 100 \%$ and $0 \% \leq$ total xylose yield $\leq$ $50 \%$, where total xylose yield $=0 \%$ and total arabinose yield $=100 \%$ corresponded to $d_{1}$ and $d_{2}$ values of 1 , and total xylose yield $=50 \%$ and total arabinose yield $=50 \%$ corresponded to $d_{1}$ and $d_{2}$ values of 0 .

RSM was also used to optimise the enzymatic hydrolysis of the BSG residue, using $3^{2}$ full factorial experimental design. The effects of the independent variables (enzyme dosage and solids loading) were investigated on the achievable glucose concentration and glucose yield (as response variables). The independent variables of enzyme dosage and solids loading were set to $0.01,0.03$, and $0.05 \mathrm{~g} / \mathrm{g}$ DM and 5,10 , and $15 w / w \%$, respectively. The statistical evaluation of the enzymatic hydrolysis was also performed by using a quadratic polynomial model. In the model equations of enzymatic hydrolysis (Equations (12) and (13)), the solids loading is referred to as SL expressed in \%, and the enzyme dosage is referred to E expressed in $\mathrm{g} / \mathrm{g}$ DM.

\section{Results and Discussion}

3.1. Optimisation of the First Acidic Hydrolysis of BSG to Produce an Arabinose-Rich Hydrolysate

The BSG contained $17.9 \%$ glucan (from this $3.2 \%$ is starch), $15.0 \%$ xylan, $7.4 \%$ arabinan, $19.0 \%$ Klason-lignin, $32.6 \%$ crude protein, and $4.0 \%$ inorganic compounds on dry basis. The aim of the first acidic treatment was to preferentially release arabinose from BSG, and meanwhile retain the xylan and glucan part insoluble, resulting in a liquid fraction with arabinose as the main constituent and a solid fraction containing the main part of the initial xylan and glucan content of BSG. The effects of the reaction time and sulphuric acid concentration both on total and monomer yields of glucose, xylose, and arabinose 
were investigated, and the optimal reaction conditions in terms of the production of an arabinose-rich hydrolysate were determined.

The results of the full factorial $\left(3^{2}\right)$ experimental design were shown in Table 1 . The linear terms of time and sulphuric acid concentration had significant effects on all of the investigated response variables, except on the monomer xylose yield, where the quadratic term of time and the interaction between time and acid concentration also had significant effects (Equations (3)-(8)). Increasing the acid concentration and reaction time of the first acidic hydrolysis resulted in increasing monomer and total sugar yields throughout the experimental design (Figure 1). The linear term of the sulphuric acid concentration had the highest effect on the achievable sugar yields in all of the cases, except on the total glucose yield, where the linear term of the reaction time had (Figure S1).

$$
\begin{gathered}
\text { Total glucose yield }=0.87+0.15 \times \mathrm{T}+3.53 \times \mathrm{S} \\
\text { Total xylose yield }=-5.95+0.49 \times \mathrm{T}+16.37 \times \mathrm{S} \\
\text { Total arabinose yield }=10.71+0.64 \times \mathrm{T}+25.04 \times \mathrm{S} \\
\text { Monomer glucose yield }=-0.08+0.01 \times \mathrm{T}+0.34 \times \mathrm{S} \\
\text { Monomer xylose yield }=2.45-0.05 \times \mathrm{T}-4.24 \times \mathrm{S}+1.51 \times \mathrm{S}^{2}+0.10 \times \mathrm{T} \times \mathrm{S} \\
\text { Monomer arabinose yield }=-7.37+0.65 \times \mathrm{T}+29.22 \times \mathrm{S}
\end{gathered}
$$

\begin{tabular}{|c|c|c|c|c|c|c|c|c|}
\hline Runs & $\begin{array}{l}\text { Reaction } \\
\text { Time } \\
\text { (T, Min) }\end{array}$ & $\begin{array}{l}\text { Sulphuric } \\
\text { Acid Con- } \\
\text { centration } \\
(\mathrm{S}, w / w \%)\end{array}$ & $\begin{array}{c}\text { Total } \\
\text { Xylose } \\
\text { Yield } \\
(\%)\end{array}$ & $\begin{array}{c}\text { Total } \\
\text { Arabinose } \\
\text { Yield } \\
(\%)\end{array}$ & $\begin{array}{l}\text { Total } \\
\text { Glucose } \\
\text { Yield } \\
(\%)\end{array}$ & $\begin{array}{l}\text { Monomer } \\
\text { Xylose } \\
\text { Yield } \\
(\%)\end{array}$ & $\begin{array}{c}\text { Monomer } \\
\text { Arabinose } \\
\text { Yield } \\
(\%)\end{array}$ & $\begin{array}{c}\text { Monomer } \\
\text { Glucose } \\
\text { Yield } \\
(\%)\end{array}$ \\
\hline 1. & 10 & 0.50 & 9.3 & 25.2 & 5.9 & 0.5 & 11.9 & 0.3 \\
\hline 2. & 10 & 1.25 & 20.4 & 48.0 & 6.3 & 0.9 & 34.6 & 0.5 \\
\hline 3. & 10 & 2.00 & 28.5 & 67.1 & 8.2 & 1.6 & 54.2 & 0.6 \\
\hline 4. & 30 & 0.50 & 16.6 & 40.1 & 6.4 & 0.9 & 22.5 & 0.6 \\
\hline 5. (C) & 30 & 1.25 & 29.4 & 65.3 & 11.4 & 1.5 & 53.4 & 0.6 \\
\hline 6. & 30 & 2.00 & 38.9 & 74.1 & 12.6 & 4.0 & 66.2 & 1.0 \\
\hline 7. & 50 & 0.50 & 24.1 & 53.8 & 9.1 & 0.9 & 34.9 & 0.5 \\
\hline 8. & 50 & 1.25 & 36.4 & 73.3 & 13.1 & 3.1 & 64.0 & 0.9 \\
\hline 9. & 50 & 2.00 & 56.2 & 90.5 & 16.5 & 8.1 & 80.3 & 1.4 \\
\hline 10. (C) & 30 & 1.25 & 29.7 & 66.0 & 8.7 & 1.7 & 49.6 & 0.7 \\
\hline 11. (C) & 30 & 1.25 & 27.1 & 60.0 & 11.1 & 2.0 & 59.9 & 0.8 \\
\hline 12. (C) & 30 & 1.25 & 32.6 & 72.5 & 8.9 & 1.6 & 53.8 & 0.5 \\
\hline
\end{tabular}

Table 1. The experimental setup and results of the first acidic hydrolysis of BSG.

(C) refers to the centrum points of the experimental design.

The response surface of the total xylose yield clearly showed that a considerable amount of xylan was solubilised at an increased reaction time or sulphuric acid concentration, resulting in a total xylose yield of $56.2 \%$ at the harshest reaction condition ( $2 w / w \%$ sulphuric acid concentration and $50 \mathrm{~min}$ reaction time) investigated. The total glucose yields were much lower (5.9-16.5\%) than the total xylose yields $(9.3-56.2 \%)$ in all runs. The released glucose might be derived from the hydrolysis of the starch content of BSG, as the starch fraction can be easily hydrolysed by dilute sulphuric acid treatment [49]. The highest total glucose yield was $16.5 \%$. Since the starch content constitutes $17.9 \%$ of the glucan fraction in BSG, small amount of starch was probably remained in the solid fraction in all of the cases. In the harshest treatment of the first acidic hydrolysis, a total arabinose yield of $90.5 \%$ was achieved indicating that the arabinose was almost completely solubilised. The total arabinose yields were significantly higher (25.2-90.5\%) than the total yields of glucose and xylose in all runs of the designed experiments. 


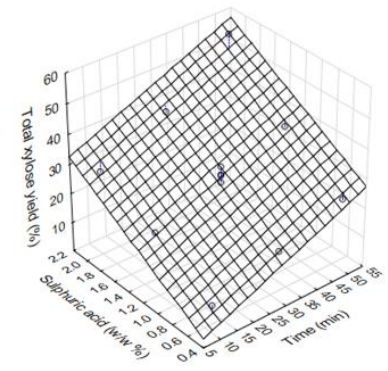

D

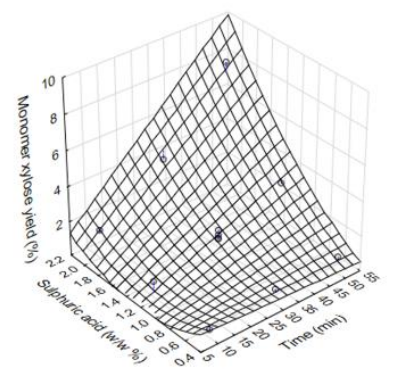

B

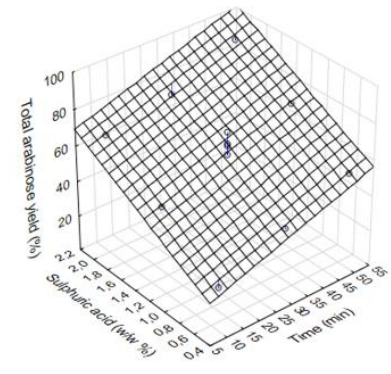

E

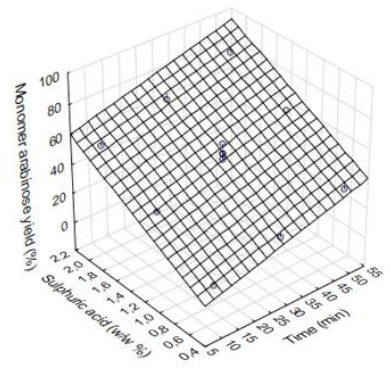

C

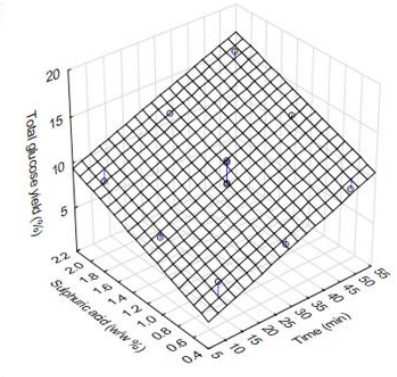

$\mathbf{F}$

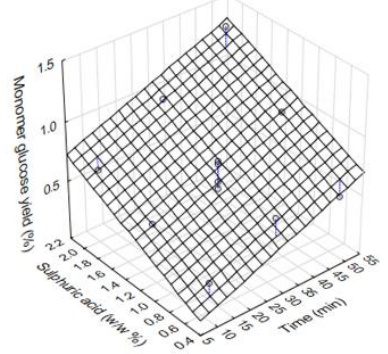

Figure 1. Fitted surfaces of the total xylose yield (A), total arabinose yield (B), total glucose yield (C), monomer xylose yield (D), monomer arabinose yield (E), and monomer glucose yield (F). Scales are fitted according to the maximum value of each response variables.

On the other hand, the monomer yields of xylose varied from 0.5 to $8.1 \%$ in the hydrolysates, which indicates that the xylan fraction is barely hydrolysed into its monomeric constituent. Thus, the xylan part was mainly present in oligomeric form in the supernatants. The monomer yields of glucose were also very low $(0.3-1.4 \%)$. It was also observed that the monomer arabinose yields were close to the total arabinose yields. Thus, the solubilised arabinose content was mainly present in monomeric form in the hydrolysates. Compared to the monomer yields of glucose and xylose, the arabinose yields were significantly higher in all of the runs.

Since the glucan and the xylan are mainly solubilised in the form of oligomers, the effects of reaction time and sulphuric acid concentration on the yields of GOS, AXOS, and A/X ratio in AXOS were also statistically evaluated. These results are shown in Table 2. The GOS and AXOS yields were varied between $5.6-15.1 \%$ and $10.4-35.7 \%$, respectively, within the investigated experimental range.

Table 2. Yields and composition (A/X ratio) of oligosaccharides obtained in the first acidic hydrolysis of BSG.

\begin{tabular}{cccc}
\hline Runs & $\begin{array}{c}\text { GOS Yield } \\
(\mathbf{\%})\end{array}$ & $\begin{array}{c}\text { AXOS Yield } \\
\mathbf{( \% )}\end{array}$ & A/X Ratio in AXOS \\
\hline 1. & 5.6 & 10.4 & 0.74 \\
2. & 5.8 & 17.6 & 0.34 \\
3. & 7.6 & 22.3 & 0.23 \\
4. & 5.8 & 16.3 & 0.55 \\
$5 .(\mathrm{C})$ & 10.8 & 23.1 & 0.22 \\
6. & 11.6 & 26.0 & 0.11 \\
7. & 8.5 & 21.7 & 0.40 \\
8. & 12.2 & 25.4 & 0.14 \\
9. & 15.1 & 35.7 & 0.10 \\
$10 .(\mathrm{C})$ & 8.0 & 20.5 & 0.20 \\
$11 .(\mathrm{C})$ & 10.4 & 24.6 & 0.20 \\
$12 .(\mathrm{C})$ & 8.4 & 22.4 & 0.20 \\
\hline
\end{tabular}

(C) refers to the centrum points of the experimental design. 
The linear terms of sulphuric acid concentration and reaction time had significant effects on the GOS and the AXOS yields (Equations (9) and (10), Figure S2). It was observed that increasing reaction time and sulphuric acid concentration continuously increased the GOS and AXOS yields (Figure 2), resulting in maximum yields of $15.1 \%$ and $35.7 \%$, respectively. AXOS yields were at least two times higher than the GOS yields in all runs. All of the terms (linear and quadratic terms of sulphuric acid concentration and reaction time and interaction between the two variables) had significant effects on the A/X ratio in AXOS (Equation (11), Figure S2). By increasing the acid concentration and reaction time of the first acidic hydrolysis, the $\mathrm{A} / \mathrm{X}$ ratio in AXOS decreased from 0.74 to 0.10 , indicating that the arabinose moieties are more sensitive for the acidic hydrolysis compared to the xylose units of the AXOS (Table 2). The linear term of sulphuric acid concentration had the major impact on both the A/X ratio and AXOS yield, however, it has a negative effect on the $A / X$ ratio but positive effect on the AXOS yield (Equations (10) and (11)). In the first run, an $A / X$ ratio of 0.74 in the solubilised $A X O S$ was observed which exceeds the $A / X$ ratio in the raw BSG (0.49). That might suggest the presence of an arabinose-rich part within the arabinoxylan of BSG, which is less recalcitrant against acidic solubilisation compared to the other part of the arabinoxylan structure. However, further studies investigating the exact structure of the solubilised oligomers are needed to confirm or contradict this hypothesis.

$$
\begin{gathered}
\text { GOS yield }=0.95+0.14 \times \mathrm{T}+3.19 \times \mathrm{S} \\
\text { AXOS yield }=4.13+0.27 \times \mathrm{T}+7.90 \times \mathrm{S} \\
(\mathrm{A} / \mathrm{X}) \text { ratio }=1.28-0.02 \times \mathrm{T}+0.00009 \times \mathrm{T}^{2}-0.94 \times \mathrm{S}+0.23 \times+0.003 \times \mathrm{T} \times \mathrm{S}
\end{gathered}
$$

A

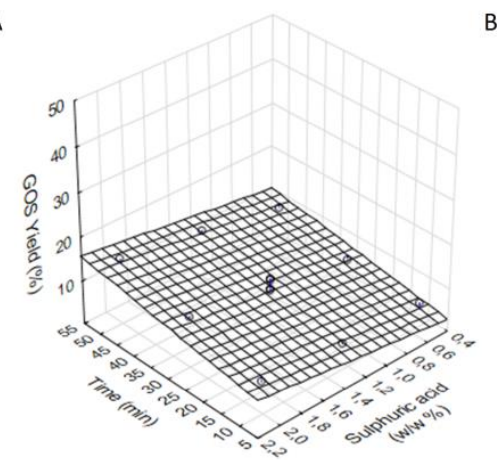

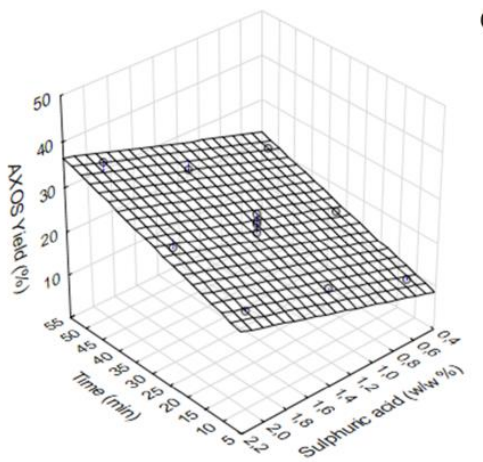

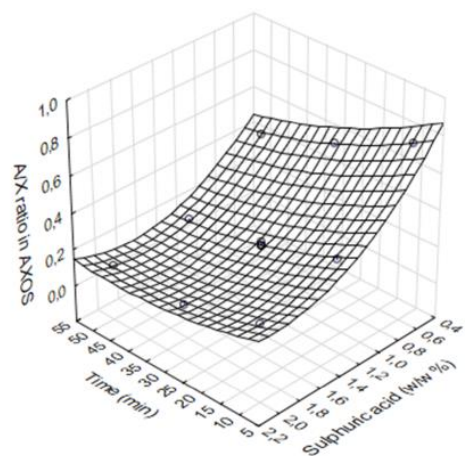

Figure 2. Fitted surfaces of the GOS yield (A), AXOS yield (B), and the A/X ratio in AXOS (C).

These results showed that under mild conditions of the first acidic hydrolysis, solubilisation of the arabinose content of BSG is more favourable compared to the hydrolysis of xylan. The arabinose is mainly liberated as monomers, meanwhile most of the solubilised xylose are present in oligomers. The cellulose fraction of the BSG glucan is probably remained intact during the first acidic hydrolysis. These results are in accord with those statements indicating that the acidic hydrolysis of arabinose side chains from AXOS is preferential over the hydrolysis of xylose units, and that the cellulose fraction is recalcitrant against the dilute acidic hydrolysis under mild conditions [50,51].

Based on the previous results, optimisation of the reaction conditions (reaction time, sulphuric acid concentration) of the first acidic hydrolysis was performed in order to solubilise a high amount of arabinose but retain the main part of the xylan in the solid fraction. To be able to find a good compromise between those contradicting aims, Dfunction approach was applied. The aim was to maximise the total arabinose yield, but at the same time keep the total xylose yield below 50\%. The optimal conditions according to the D-function optimisation were the followings: $1.85 w / w \%$ sulphuric acid concentration and $19.5 \mathrm{~min}$ reaction time (Figure S3). Under this condition, the fitted models predicted $32.3 \%, 9.8 \%$, and $69.8 \%$ total yields of xylose, glucose, and arabinose, respectively. The 
predicted values were $2.4 \%, 0.7 \%$, and $58.6 \%$ for monomer yields of xylose, glucose, and arabinose, respectively. In the case of AXOS yield and A/X ratio in AXOS, the model predicted $23.8 \%$ and 0.17 , respectively (Table 3).

Table 3. Model predictions and experimental results of the first acidic hydrolysis of BSG under optimised conditions.

\begin{tabular}{|c|c|c|c|c|c|c|c|c|}
\hline & $\begin{array}{c}\text { Total } \\
\text { Xylose } \\
\text { Yield } \\
(\%)\end{array}$ & $\begin{array}{c}\text { Total } \\
\text { Arabinose } \\
\text { Yield } \\
(\%)\end{array}$ & $\begin{array}{c}\text { Total } \\
\text { Glucose } \\
\text { Yield } \\
\text { (\%) }\end{array}$ & $\begin{array}{l}\text { Monomer } \\
\text { Xylose } \\
\text { Yield } \\
(\%)\end{array}$ & $\begin{array}{c}\text { Monomer } \\
\text { Arabinose } \\
\text { Yield } \\
\text { (\%) }\end{array}$ & $\begin{array}{l}\text { Monomer } \\
\text { Glucose } \\
\text { Yield } \\
(\%)\end{array}$ & $\begin{array}{c}\text { AXOS } \\
\text { Yield } \\
(\%)\end{array}$ & $\begin{array}{l}\text { A/X Ratio } \\
\text { in AXOS }\end{array}$ \\
\hline Predicted & 32.3 & 69.8 & 9.8 & 2.4 & 58.6 & 0.7 & 23.8 & 0.17 \\
\hline $\begin{array}{l}-95 . \% \\
\text { Conf. }\end{array}$ & 28.4 & 60.6 & 7.3 & 2.0 & 51.0 & 0.5 & 20.7 & 0.15 \\
\hline $\begin{array}{l}+95 . \% \\
\text { Conf. }\end{array}$ & 36.3 & 78.9 & 12.3 & 2.8 & 66.2 & 0.9 & 26.9 & 0.18 \\
\hline $\begin{array}{l}-95 . \% \\
\text { Pred. }\end{array}$ & 24.2 & 51.1 & 4.7 & 1.5 & 43.1 & 0.3 & 17.5 & 0.13 \\
\hline +95.\% Pred. & 40.5 & 88.4 & 14.9 & 3.2 & 74.1 & 1.2 & 30.1 & 0.20 \\
\hline $\begin{array}{c}\text { Measured } \\
\text { average }\end{array}$ & 36.1 & 75.7 & 13.0 & 2.2 & 65.5 & 0.5 & 26.1 & 0.15 \\
\hline $\begin{array}{l}\text { Standard } \\
\text { deviation }\end{array}$ & 2.2 & 5.0 & 1.0 & 0.3 & 4.4 & 0.2 & 1.6 & 0.01 \\
\hline
\end{tabular}

To validate the fitted models and obtain a liquid fraction with high arabinose content and a solid fraction containing the main part of the xylan of raw BSG, experiments under the optimised conditions were performed. The first acidic hydrolysis of BSG under the optimised conditions resulted in 36.1\% total xylose yield, 13.0\% total glucose yield, 75.7\% total arabinose yield, 2.2\% monomer xylose yield, 0.5\% monomer glucose yield, 65.5\% monomer arabinose yield, 26.1\% AXOS yield, and $0.15 \mathrm{~A} / \mathrm{X}$ ratio in the solubilised AXOS. Based on these, all of the response variables fit well into the prediction intervals of the models (Table 3), which proves that the models are adequate. Moreover, the measured values were also within the confidence intervals (except total glucose yield), indicating the high accuracy of the models. These could allow us to vary the amount of solubilised sugars, sugar oligomers, and the composition (A/X ratio) of the solubilised arabinoxylooligomers by changing the reaction conditions according to our aims. In order to test the reproducibility of the experiments and reaffirm the reliability of the model predictions, measurements under the optimised conditions were repeated with a new sample of BSG. In this case, $11.9 \%$ total glucose yield, $29.9 \%$ total xylose yield, and $69.7 \%$ total arabinose yield were achieved. All of these values fall into the confidence interval of the model.

$\mathrm{Xu}$ et al. [52] published a method to separate an arabinose fraction from corn stover by acetic acid hydrolysis. They achieved a total arabinose yield of $52.2 \%$ by using $0.01 \mathrm{~g} / \mathrm{g}$ acetic acid at $195^{\circ} \mathrm{C}$ for $15 \mathrm{~min}$. The yield of monomer arabinose (18.7\%) was lower than the yield of arabinose in oligomeric form (24.9\%). In our study higher total arabinose yield was reached $(75.7 \%)$ and the arabinose was mainly obtained in monomeric form $(65.5 \%)$. Shibanuma et al. [53] investigated the selective arabinose release from corn fibre with different diluted acids. In the optimum conditions $\left(0.3 \mathrm{~N}\right.$ oxalic acid at $100{ }^{\circ} \mathrm{C}$ for $100 \mathrm{~min}$ ), the arabinose and xylose yields were $55 \%$ and $15 \%$, respectively. Compared to this, both of the total arabinose and xylose yields were higher in our study. In our previous studies, optimisation of mild sulphuric acid pre-treatments of wheat bran and corn fibre was performed to obtain arabinose-rich hydrolysates. The arabinose yields achieved by using wheat bran $(73.7 \%)$ and corn fibre $(75.9 \%)$ were similar to that obtained in this study $[43,44]$. Several studies investigated the sulphuric acid hydrolysis of BSG, however, they mainly aimed to solubilise the whole hemicellulose fraction in a one-step process. Solubilising the whole hemicellulose fraction in one step results in a liquid fraction with 
higher xylose and lower arabinose concentration [54-56], however making the separated use of arabinose and xylose more difficult.

The liquid fraction derived from the optimised first acidic hydrolysis of BSG contained $0.4 \mathrm{~g} / \mathrm{L}$ xylose, $6.2 \mathrm{~g} / \mathrm{L}$ arabinose, and $6.6 \mathrm{~g} / \mathrm{L}$ AXOS. The amounts of inhibitors (acetic acid, formic acid, HMF, furfural, and total phenol) were also determined. The acetic acid, formic acid, and total phenol concentrations were $0.4 \mathrm{~g} / \mathrm{L}, 0.1 \mathrm{~g} / \mathrm{L}$, and $0.6 \mathrm{~g} / \mathrm{L}$, respectively. On the other hand, HMF and furfural were not present in detectable amounts. The first acidic hydrolysis was also repeated by using higher weights of the reaction mixtures $(100 \mathrm{~g}, 400 \mathrm{~g}$, and $800 \mathrm{~g}$ ), resulting in similar results in all of the cases. In the case of the reaction mixture of $800 \mathrm{~g}, 74.5 \%$ total arabinose yield, $37.5 \%$ total xylose yield, $13.2 \%$ total glucose yield, $61.1 \%$ monomer arabinose yield, $3.9 \%$ monomer xylose yield, $1.3 \%$ monomer glucose yield, $27.4 \%$ AXOS yield, and $0.20 \mathrm{~A} / \mathrm{X}$ ratio were obtained.

The supernatants were analysed by TLC in order to qualitatively evaluate the composition of the AXOS fraction. According to the TLC analysis, the main fraction of the solubilised oligosaccharides was probably xylobiose (Figure S4). The monomer arabinose and (A)XOS could be separated by different membrane and chromatographic methods in order to obtain pure arabinose-rich and an (A)XOS-rich solutions [57,58]. A promising method for that was investigated by Wijaya et al. [59] and it included the combination of ultra- and nanofiltrations. After the filtration steps, $90.1 \%$ xylose recovery was achieved from a xylooligosaccharides-rich, empty fruit brunch hydrolysate [59]. Hence, the first acidic hydrolysate of BSG might be further processed by membrane technology to obtain pure arabinose and AXOS-rich solutions [59] for the production of crystalline arabinose and AXOS preparation, respectively. Arabinose can be used as a platform molecule for drug synthesis in the pharmaceutical industry or as a healthy sweetener in the food industry [51], while AXOS might be used as prebiotic substance in functional foods, among other possible applications [60,61].

After the first acidic treatment of BSG under optimised conditions, a solid fraction containing $18.4 \%$ glucan (from this $1.0 \%$ starch), $12.7 \%$ xylan, $1.4 \%$ arabinan, and $19.4 \%$ Klason-lignin (on dry basis) was obtained. The presence of a small amount of starch in the solid residue is in accord with the total glucose yield of 13\% during the optimised first acidic hydrolysis. This confirms that the solubilised glucose was probably derived only from starch, and the cellulose fraction was remained intact in this step. The solid faction was used in the second acidic hydrolysis step.

\subsection{Solubilisation of the Hemicellulose Fraction from the Solid Residue of the First Acidic Hydrolysis of BSG}

The aim of the second acidic hydrolysis was to release the remained hemicellulose fraction from the solid residue obtained after the optimised first acidic hydrolysis of BSG, in order to produce a liquid fraction with high xylose content and a solid fraction with enhanced glucan (cellulose) content.

The second acidic hydrolysis was performed by using $1 w / w \%$ sulphuric acid concentration at elevated temperature $\left(121^{\circ} \mathrm{C}\right)$, which resulted in the complete decomposition of the solubilised polysaccharides. As the solubilised sugars were only present in monomeric form in the hydrolysate, total and monomer sugar yields were equal in this case. A xylose yield of $89.7 \%$ and complete arabinose solubilisation were achieved, indicating that the solubilisation of the remaining hemicellulose fraction was successful. The glucose yield was $14.2 \%$, suggesting that in addition to the residual starch, other parts of the glucan fraction (cellulose or $\beta$-glucan) were also partially hydrolysed. In our previous studies, dilute sulphuric acid treatments of pre-treated corn fibre and wheat bran using similar reaction conditions were investigated $[43,44]$. In those studies, similar results were obtained resulting in the solubilisation of the hemicellulose fraction, and production of a glucan-enhanced solid fraction.

The liquid fraction, obtained after the second acidic hydrolysis, contained $14.5 \mathrm{~g} / \mathrm{L}$ xylose, $3.2 \mathrm{~g} / \mathrm{L}$ glucose, and $1.9 \mathrm{~g} / \mathrm{L}$ arabinose. The xylose concentration was significantly higher than that of the glucose and arabinose, thus the hydrolysate was referred to as a 
xylose-enriched hydrolysate. However, the xylose concentration was lower than those obtained in our previous studies using wheat bran $(21.3 \mathrm{~g} / \mathrm{L})$ and corn fibre $(28 \mathrm{~g} / \mathrm{L})$. On the other hand, the initial xylan content of the wheat bran $(20.7 \%)$ and corn fibre $(19 \%)$ were higher than the xylan content of BSG (13.1\%) [43,44]. The xylose-enriched hydrolysate of BSG could serve as a raw material for xylitol production [18] or other fermentative bio-processes [62]. Xylitol could be also a high-value product in a BSG biorefinery due to its wide applicability in the food, cosmetic, and pharmaceutical industry [63,64].

Inhibitor compounds in the second acidic hydrolysate of BSG were also quantified. The acetic acid, formic acid, and total phenol concentrations were $1.3 \mathrm{~g} / \mathrm{L}, 0.6 \mathrm{~g} / \mathrm{L}$, and $2.2 \mathrm{~g} / \mathrm{L}$, respectively, while HMF and furfural were not detected. Compared to the first acidic hydrolysate, the concentrations of organic acids and phenolic compounds were increased. The remaining solid fraction after the second acidic hydrolysis of BSG contained $32.2 \%$ glucan, $5.1 \%$ xylan, and $31.1 \%$ Klason-lignin on dry basis. Arabinan was not detected. These results confirmed that a solid fraction with enhanced glucan content was obtained after the second hydrolytic process step.

\subsection{Optimisation of the Enzymatic Hydrolysis of the Solid Resiude Obtained in the Second Acidic Hydrolysis of BSG}

The aim of the enzymatic hydrolysis was to hydrolyse the cellulose content from the solid residue of the second acidic hydrolysis of BSG, and thus result in a liquid fraction with high glucose concentration. The effects of the enzyme dosage and solids loading on the achievable glucose yield and concentration were investigated. Optimisation was also accomplished in order to maximize the efficiency of the enzymatic hydrolysis, and thus enhance the bioethanol production in the following process step. Results of the enzymatic hydrolysis experiments are shown in Table 4.

Table 4. The experimental set and results of the enzymatic hydrolysis of BSG residue.

\begin{tabular}{|c|c|c|c|c|}
\hline Runs & $\begin{array}{c}\text { Enzyme Dosage } \\
\text { (E,g/g DM) }\end{array}$ & $\begin{array}{l}\text { Solids Loading } \\
\qquad(w / w \%)\end{array}$ & $\begin{array}{c}\text { Glucose } \\
\text { Concentration } \\
(\mathrm{g} / \mathrm{L})\end{array}$ & $\begin{array}{l}\text { Glucose Yield } \\
(\%)\end{array}$ \\
\hline 1. & 0.01 & 5 & 10.3 & 54.5 \\
\hline 2. & 0.01 & 10 & 19.4 & 48.9 \\
\hline 3. & 0.01 & 15 & 33.9 & 53.7 \\
\hline 4. & 0.03 & 5 & 12.6 & 66.8 \\
\hline 5. (C) & 0.03 & 10 & 30.8 & 77.6 \\
\hline 6. & 0.03 & 15 & 43.9 & 69.6 \\
\hline 7. & 0.05 & 5 & 12.9 & 68.4 \\
\hline 8. & 0.05 & 10 & 30.0 & 78.0 \\
\hline 9. & 0.05 & 15 & 49.2 & 77.9 \\
\hline 10. (C) & 0.03 & 10 & 30.5 & 76.7 \\
\hline 11. (C) & 0.03 & 10 & 29.5 & 74.2 \\
\hline 12. (C) & 0.03 & 10 & 28.6 & 71.9 \\
\hline
\end{tabular}

(C) refers to the centrum points of the experimental design.

The glucose concentration and yield were varied between 10.3-49.2 g/L and 48.9$78.0 \%$, respectively, within the investigated experimental range. On the glucose yield, only the linear and quadratic terms of the enzyme dosage had significant effects (Equation (12)). By changing the enzyme dosage from 0.04 to $0.05 \mathrm{~g} / \mathrm{g} \mathrm{DM}$, the glucose yield did not change considerably according to the fitted surface (Figure 3), however, the highest glucose yield $(78.0 \%)$ was measured at the enzyme dosage of $0.05 \mathrm{~g} / \mathrm{g} \mathrm{DM}$ and solid loadings of $10 w / w \%$ (Table 4 ). On glucose concentration, the linear terms of enzyme dosage and solids loading, the quadratic term of enzyme dosage and the interaction between the two independent variables had significant effects (Equation (13)). The glucose concentration continuously increased by increasing the enzyme dosage and solids loading, reaching a maximum glucose concentration of $49.2 \mathrm{~g} / \mathrm{L}$ at $0.05 \mathrm{~g} / \mathrm{g}$ DM enzyme dosage 
and $15 w / w \%$ solids loading. The fitted model of the glucose concentration showed that the enzyme dosage had less influence on it compared to the solid loadings (Figure S5). The fitted surface suggested that increasing the enzyme dosage and solids loading beyond the experimental range would further increase the glucose concentration. Several studies observed increasing glucose concentration by increasing the solids loading during the enzymatic hydrolysis process step [65-67]. However, there could be a negative correlation between the solids loading and glucan conversion yield [68,69]. López-Linares et al. [70] published a decreasing tendency of glucose yield from $75 \%$ to $64.5 \%$ by changing the solids loading from 7.5 to $20 \%$ in the case of enzymatic hydrolysis of rapeseed straw. On the other hand, Manzanares et al. [71] observed that increasing solids loading up to $17 \%$ did not reduce significantly the glucose yield in the case of enzymatic hydrolysis of pre-treated olive tree pruning residues. Wilkinson et al. [72] reported that the glucose yield decreased when the solids loading exceeded $15 \%$ in the case of the enzymatic hydrolysis of BSG treated by acid-catalysed hydrothermal method. However, in despite of the decreased glucose yield, the glucose concentration was further increased. Rojas-Chamorro et al. [73] reached the highest glucose concentration $(59.4 \mathrm{~g} / \mathrm{L})$ at $15 \%$ solids loading in the case of BSG treated by phosphoric acid, where the highest glucose yield was also obtained (99.7\%). In our study, the glucose yield did not decrease by increasing the solids loading up to $15 w / w \%$, thus the highest glucose concentration was reached at the point of the highest glucose yield.

A

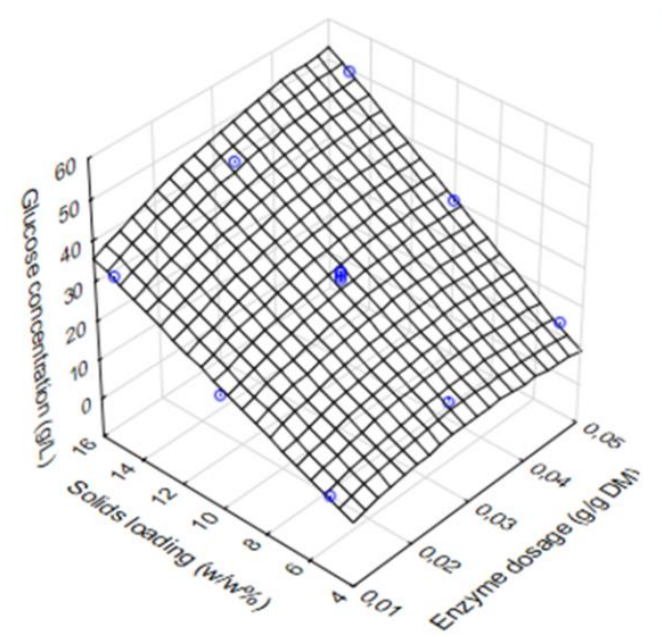

B

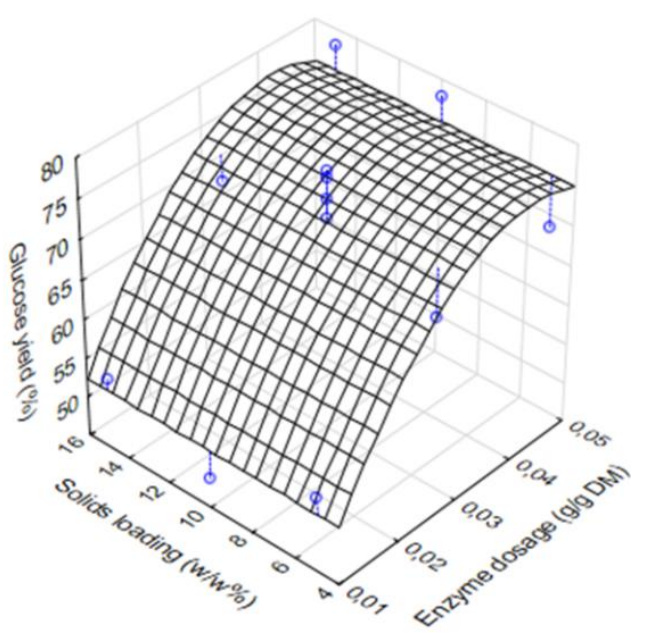

Figure 3. Fitted surfaces of glucose concentration (A) and glucose yield (B) obtained in designed experiments of the enzymatic hydrolysis step.

Since the glucose yield did not increase significantly by using an enzyme dosage higher than $0.04 \mathrm{~g} / \mathrm{g} \mathrm{DM}$, and the enzyme dosage had less influence on the glucose concentration, an optimum condition of $0.04 \mathrm{~g} / \mathrm{g}$ DM enzyme dosage and $15 \mathrm{w} / \mathrm{w} \%$ solids loading was chosen for further experiments. D-function was not used for optimisation in this case, since the glucose concentration clearly depends on the solids loading. Therefore, exact values cannot be assigned to the desired intervals of glucose concentration. The solids loading was not further increased due to the inhomogeneity and mixing problems possibly occurring due to such high dry matter contents. The predicted values of the glucose yield and concentration according to the fitted models under the selected condition $(0.04 \mathrm{~g} / \mathrm{g} \mathrm{DM}$ enzyme dosage and $15 w / w \%$ solids loading) were $76.1 \%$ and $47.7 \mathrm{~g} / \mathrm{L}$ with the predicted intervals of $67.4-84.8 \%$ and $43.9-51.4 \mathrm{~g} / \mathrm{L}$, respectively.

$$
\text { Glucose yield }=35.25+1943.36 \times \mathrm{E}-23054.41 \times \mathrm{E}^{2}
$$

Glucose concentration $=-6.32+426.31 \times \mathrm{E}-8425.04 \times \mathrm{E}^{2}+2.09 \times \mathrm{SL}+31.64 \times \mathrm{E} \times \mathrm{SL}$ 
To validate the models, enzymatic hydrolysis was carried out under the selected condition. The achieved glucose yield and glucose concentration were $75.5 \%$ and $46.1 \mathrm{~g} / \mathrm{L}$, respectively. These results were within the predicted intervals; thus, the fitted models were adequate. These results were also within the confidence intervals $(73.0-79.2 \%$ and $45.67-49.64 \mathrm{~g} / \mathrm{L}$ in the cases of glucose yield and concentration, respectively) indicating the high accuracy of the models. On the other hand, both response parameters were lower than the highest values obtained during the experimental design $(49.2 \mathrm{~g} / \mathrm{L}$ glucose concentration and $78.0 \%$ glucose yield), however, the differences were not considerable. Moreover, using a lower enzyme dosage $(0.04 \mathrm{~g} / \mathrm{g}$ instead of $0.05 \mathrm{~g} / \mathrm{g})$ is probably more advantageous from an economic point of view.

As the initial feedstock (solid residue derived from the second acidic hydrolysis of BSG) of the enzymatic hydrolysis still contained some residual xylan, a small amount of xylose was released during the enzymatic hydrolysis (62.1\% xylose yield), resulting in $6.7 \mathrm{~g} / \mathrm{L}$ xylose concentration in the hydrolysate.

\subsection{Bioethanol Production}

An ethanol fermentation experiment was performed on the hydrolysate obtained after the optimised enzymatic hydrolysis. The fermentation profile is shown in Figure 4.
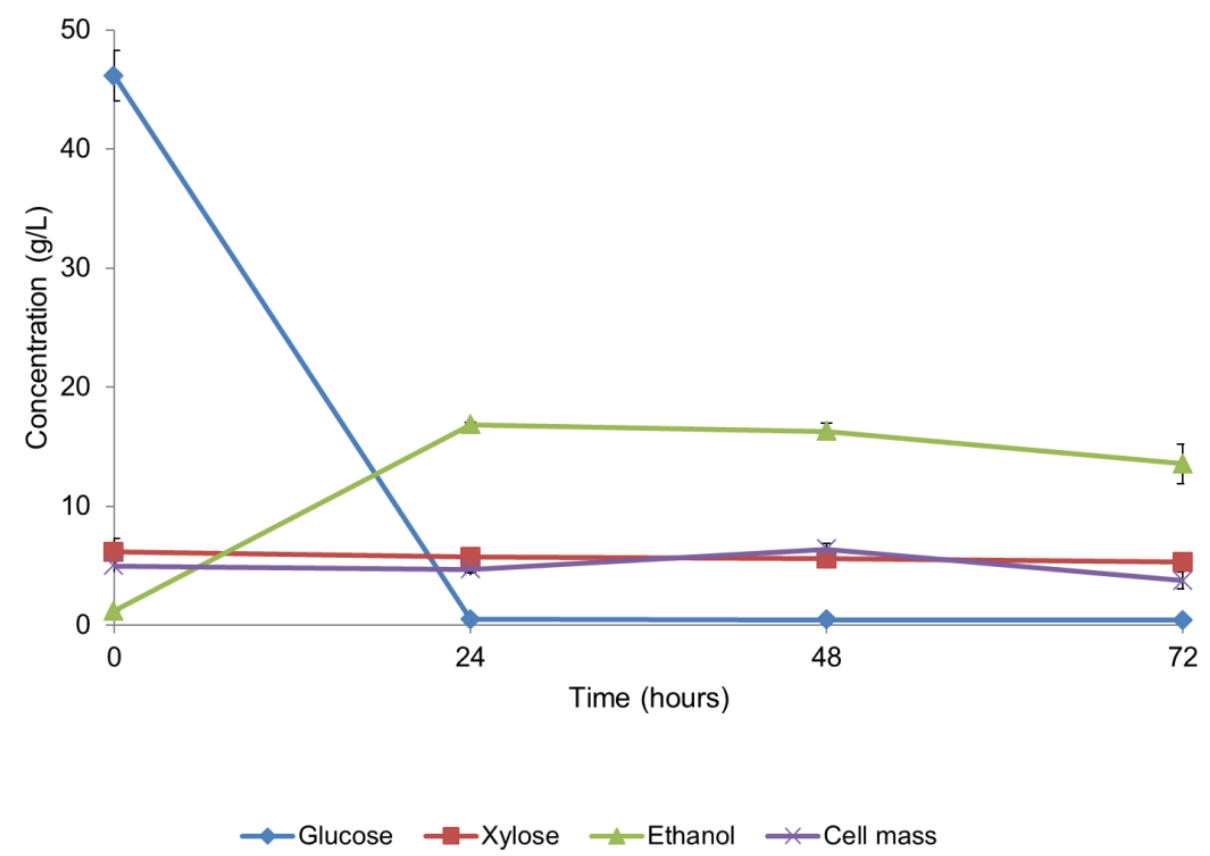

Figure 4. Profile of bioethanol production by S. cerevisiae on optimised enzymatic hydrolysate of BSG residue. Standard deviations are calculated from duplicates.

The glucose content was almost completely consumed within $24 \mathrm{~h}$ of ethanol fermentation. In the cell concentration ( $5 \mathrm{~g} / \mathrm{L}$ initial concentration), a slight decrease was observed during the fermentation, resulting in $4 \mathrm{~g} / \mathrm{L}$ at the end. The xylose concentration did not change considerably as the baker's yeast (S. cerevisiae) cannot use the pentose sugars efficiently $[74,75]$. Thus, the ethanol production was completed after $24 \mathrm{~h}$. The maximum concentration of ethanol was $16.9 \mathrm{~g} / \mathrm{L}$ and it was reached after $24 \mathrm{~h}$. After reaching the maximum ethanol concentration, the amount of ethanol was slightly decreased until the end of the fermentation, probably due to a slow evaporation. The ethanol yield and ethanol volumetric productivity at $24 \mathrm{~h}$ of fermentation were $71.6 \%$ (of theoretical) and $0.72 \mathrm{~g} /(\mathrm{L} \times \mathrm{h})$, respectively.

Liguori et al. [22] investigated the bioethanol production by Saccharomyces cerevisiae NRRL YB 2293 on a glucose-rich, enzymatic hydrolysate of alkali pre-treated BSG (50 g/L initial glucose concentration). The obtained ethanol yield and concentration were $51 \%$ and 
$12 \mathrm{~g} / \mathrm{L}$ after $48 \mathrm{~h}$ [22]. Wilkinson et al. [76] reached $81 \%$ ethanol yield and $17.3 \mathrm{~g} / \mathrm{L}$ ethanol concentration on glucose-rich BSG hydrolysate $(41.3 \mathrm{~g} / \mathrm{L}$ initial glucose concentration) by $S$. cerevisiae. Rojas-Chamorro et al. [73] achieved $72 \%$ ethanol yield by $S$. cerevisiae after $24 \mathrm{~h}$ on glucose-rich BSG hydrolysate. The produced bioethanol was $22.9 \mathrm{~g} / \mathrm{L}$ from $59.4 \mathrm{~g} / \mathrm{L}$ initial glucose concentration [73]. These results by $S$. cerevisiae are similar to those achieved in our study $(16.9 \mathrm{~g} / \mathrm{L}$ ethanol concentration and $71.6 \%$ ethanol yield from $46.1 \mathrm{~g} / \mathrm{L}$ initial glucose concentration). On the other hand, if the ethanol yield would be calculated from the total amount of sugars (glucose and xylose), an ethanol yield of $64.3 \%$ would be obtained. This yield could be further enhanced by microorganisms that co-utilise pentose and hexose sugars. Rojas-Chamorro et al. [77] achieved an ethanol yield of $86 \%$ by E. coli SL100 on a BSG hydrolysate with high xylose content. However, they reached the maximum ethanol yield after $91 \mathrm{~h}$ of fermentation due to the slower utilisation of xylose [77]. White et al. [78] also investigated the use of xylose and arabinose on BSG hydrolysate by Pichia stiptitis and Kluyveromyces marxianus. The achieved ethanol yields were $0.32 \mathrm{~g}$ ethanol/g substrate and $0.23 \mathrm{~g}$ ethanol/g substrate after $48 \mathrm{~h}$ by P. stiptitis and K. marxianus, respectively [78].

\section{Conclusions}

A novel fractionation process consisting of sequential acidic and enzymatic hydrolysis steps was developed and optimised in order to obtain a liquid stream rich in arabinose and AXOS, a xylose-rich hydrolysate, and a supernatant containing high concentration of glucose from BSG. During the first acidic hydrolysis of BSG, the amount of the solubilised arabinose, xylose, and AXOS and the composition (A/X ratio) of the AXOS fraction are variable by controlling the process conditions (reaction time and acid concentration) due to the validated models fitted to the experimental data. The arabinose and AXOS, produced in the optimised first acidic hydrolysis, can act as high-value products of a biorefinery processing BSG. In the second acidic hydrolysis, the remaining hemicellulose fraction was solubilised, resulting in a xylose-rich hydrolysate. In the final step of the BSG fractionation, a cellulose-rich solid residue was obtained, which is suitable for the production of biofuels (e.g., biogas, bioethanol) or higher value bio-products (e.g., lactic acid). Based on theoretical calculations, bioethanol and biogas productions from the cellulose-rich solid fraction of BSG provide quite similar alternatives in terms of the achievable energy from the obtained products (6274 and $6827 \mathrm{MJ} /$ dry tonne of cellulose-rich residue in the cases of bioethanol and biogas production, respectively). Since bioethanol has a wide range of use in biobased industries, in this study we focused on bioethanol production. The enzymatic treatment of the cellulose-rich fraction was optimised to produce a glucose-rich hydrolysate. The glucose-rich hydrolysate was found to be an excellent raw material for bioethanol fermentation by using commercial baker's yeast. This hydrolysate did not require previous detoxification steps or addition of nutrients for the efficient glucose to ethanol conversion. Assuming $100 \mathrm{~g}$ of dry BSG, $5.5 \mathrm{~g}$ arabinose, and $6.6 \mathrm{~g}$ AXOS can be produced in the first step of our process. After the first step, around $70 \mathrm{~g}$ of dry residue can be recovered and used in the second step, where $9.7 \mathrm{~g}$ xylose can be produced. After the second step, $30 \mathrm{~g}$ of dry residue can be obtained for processing in the enzymatic hydrolysis. Fermentation of the enzymatic hydrolysate can produce $3 \mathrm{~g}$ bioethanol. The developed and optimised fractionation process could serve as a key step for the efficient valorisation of BSG in a biorefinery process producing bioethanol and high-value bio-products (based on the hemicellulosic sugars and sugar oligomers). However, valorisation of the by-products and side streams of the proposed process is also of great importance in obtaining an economically viable, BSG-based biorefinery process. The solid residue of the enzymatic cellulose hydrolysis is rich in lignin, while the liquid fractions derived from the acidic hydrolyses might contain significant amount of proteins and other valuable bioactive substances. The efficient separation and valorisation of those components would also be important in a complex biorefinery process using BSG as a raw material. 
Supplementary Materials: The following are available online at https:/ / www.mdpi.com/2227-9 717/9/2/366/s1, Figure S1: Pareto charts of the total xylose yield (A), total arabinose yield (B), total glucose yield (C), monomer xylose yield (D), monomer arabinose yield (E) and monomer glucose yield (F), Figure S2: Pareto charts of the GOS yield (A), AXOS yield (B) and the A/X ratio in AXOS (C), Figure S3: The optimised conditions of the first acidic hydrolysis obtained by D-function approach, Figure S4: TLC analysis of the optimised first acidic hydrolysate. G: glucose, A: arabinose, C: cellobiose, $\mathrm{X} 1$ : xylose, $\mathrm{X} 2$ : xylobiose, $\mathrm{X} 3$ : xylotriose, $\mathrm{X} 4$ : xylotetraose, $\mathrm{X} 5$ : xylopentaose, $\mathrm{X} 6$ : xylohexaose S1-S3: hydrolysates obtained under optimised conditions of the first acidic hydrolysis step, Figure S5: Pareto charts of glucose concentration (A) and glucose yield (B) obtained in designed experiments of the enzymatic hydrolysis process step.

Author Contributions: S.B. analysed the data and wrote the manuscript. A.F., M.R. and L.N. conducted experiments. C.F. conceived and designed the research, was responsible for funding acquisition and corrected the manuscript. All authors have read and agreed to the published version of the manuscript.

Funding: The authors gratefully acknowledge the projects of TNN_16-123305 of the National Research, Development and Innovation Fund of Hungary, and VEKOP-2.3.2-16-2017-00013 supported by the European Union, the State of Hungary and the European Regional Development Fund for their financial support. This article is based upon work from COST Action (CA18229, Yeast4Bio), supported by COST (European Cooperation in Science and Technology, www.cost.eu). The research reported in this paper and carried out at BME has been supported by the NRDI Fund (TKP2020 IES, Grant No. BME-IE-BIO) based on the charter of bolster issued by the NRDI Office under the auspices of the Ministry for Innovation and Technology.

Institutional Review Board Statement: Not applicable.

Informed Consent Statement: Not applicable.

Data Availability Statement: The data presented in this study are available on request from the corresponding author. The data are not publicly available due to privacy restrictions.

Acknowledgments: The authors are grateful to Dreher Co. Ltd. (Budapest, Hungary) for kindly providing research material; and to JFermi Biotechnology Ltd. (Hungary) and Kinga Kóder for technical support.

Conflicts of Interest: The authors declare no conflict of interest. The funders had no role in the design of the study; in the collection, analyses, or interpretation of data; in the writing of the manuscript, or in the decision to publish the results.

\section{References}

1. Mussatto, S.I. Brewer's spent grain: A valuable feedstock for industrial applications. J. Sci. Food Agric. 2014, 94, 1264-1275. [CrossRef] [PubMed]

2. Mussatto, S.I.; Dragone, G.; Roberto, I.C. Brewers' spent grain: Generation, characteristics and potential applications. J. Cereal Sci. 2006, 43, 1-14. [CrossRef]

3. Xiros, C.; Christakopoulos, P. Biotechnological potential of brewers spent grain and its recent applications. Waste Biomass Valoriz. 2012, 3, 213-232. [CrossRef]

4. Stroem, L.K.; Desai, D.K.; Hoadley, A.F.A. Superheated steam drying of Brewer's spent grain in a rotary drum. Adv. Powder Technol. 2009, 20, 240-244. [CrossRef]

5. Westendorf, M.L.; Wohlt, J.E. Brewing by-products: Their use as animal feeds. Vet. Clin. N. Am. Food Anim. Pract. 2002, 18, 233-252. [CrossRef]

6. Weger, A.; Binder, S.; Franke, M.; Hornung, A.; Ru, W.; Mayer, W. Solid biofuel production by mechanical pre-treatment of brewers' spent grain. Chem. Eng. Trans. 2014, 37, 661-666.

7. Azevedo Borges, C.; Géczi, G.; Kovács, K.; Horváth, M.; Bácskai, I.; Korzenszky, P. Examination of energy recovery of brewers' spent grain I.-Chemical process. J. Microbiol. Biotechnol. Food Sci. 2015, 5, 116-119. [CrossRef]

8. Bochmann, G.; Drosg, B.; Fuchs, W. Anaerobic digestion of thermal pretreated brewers' spent grains. Environ. Prog. Sustain. Energy 2015, 34, 1092-1096. [CrossRef]

9. Waters, D.M.; Jacob, F.; Titze, J.; Arendt, E.K.; Zannini, E. Fibre, protein and mineral fortification of wheat bread through milled and fermented brewer's spent grain enrichment. Eur. Food Res. Technol. 2012, 235, 767-778. [CrossRef]

10. D'Appolonia, B.L.; Prentice, N. High-Fiber Bread Containing Brewer's Spent Grain. Cereal Chem. 1977, 54, 1084-1095.

11. Lynch, K.M.; Steffen, E.J.; Arendt, E.K. Brewers' spent grain: A review with an emphasis on food and health. J. Inst. Brew. 2016, 122, 553-568. [CrossRef] 
12. Shen, Y.; Abeynayake, R.; Sun, X.; Ran, T.; Li, J.; Chen, L.; Yang, W. Feed nutritional value of brewers' spent grain residue resulting from protease aided protein removal. J. Anim. Sci. Biotechnol. 2019, 10, 1-10. [CrossRef] [PubMed]

13. McCarthy, A.L.; O'Callaghan, Y.C.; Piggott, C.O.; FitzGerald, R.J.; O'Brien, N.M. Brewers' spent grain; Bioactivity of phenolic component, its role in animal nutrition and potential for incorporation in functional foods: A review. Proc. Nutr. Soc. 2013, 72, 117-125. [CrossRef]

14. Leite, P.; Silva, C.; Salgado, J.M.; Belo, I. Simultaneous production of lignocellulolytic enzymes and extraction of antioxidant compounds by solid-state fermentation of agro-industrial wastes. Ind. Crops Prod. 2019, 137, 315-322. [CrossRef]

15. Tan, Y.X.; Mok, W.K.; Lee, J.; Kim, J.; Chen, W.N. Solid state fermentation of Brewers' spent grains for improved nutritional profile using Bacillus subtilis WX-17. Fermentation 2019, 5, 52. [CrossRef]

16. Terrasan, C.R.F.; Carmona, E.C. Solid-state fermentation of brewer's spent grain for xylanolytic enzymes production by Penicillium janczewskii and analyses of the fermented substrate. Biosci. J. 2015, 31, 1826-1836. [CrossRef]

17. Mussatto, S.I.; Roberto, I.C. Chemical characterization and liberation of pentose sugars from brewer's spent grain. J. Chem. Technol. Biotechnol. 2006, 81, 268-274. [CrossRef]

18. Mussatto, S.I.; Roberto, I.C. Acid hydrolysis and fermentation of brewer's spent grain to produce xylitol. J. Sci. Food Agric. 2005, 85, 2453-2460. [CrossRef]

19. Paz, A.; Outeiriño, D.; Pérez Guerra, N.; Domínguez, J.M. Enzymatic hydrolysis of brewer's spent grain to obtain fermentable sugars. Bioresour. Technol. 2019, 275, 402-409. [CrossRef] [PubMed]

20. Amorim, C.; Silvério, S.C.; Silva, S.P.; Coelho, E.; Coimbra, M.A.; Prather, K.L.J.; Rodrigues, L.R. Single-step production of arabino-xylooligosaccharides by recombinant Bacillus subtilis 3610 cultivated in brewers' spent grain. Carbohydr. Polym. 2018, 199, 546-554. [CrossRef] [PubMed]

21. Amorim, C.; Silvério, S.C.; Rodrigues, L.R. One-step process for producing prebiotic arabino-xylooligosaccharides from brewer's spent grain employing Trichoderma species. Food Chem. 2019, 270, 86-94. [CrossRef]

22. Liguori, R.; Soccol, C.R.; de Souza Vandenberghe, L.P.; Woiciechowski, A.L.; Faraco, V. Second generation ethanol production from brewers' spent grain. Energies 2015, 8, 2575-2586. [CrossRef]

23. Brethauer, S.; Wyman, C.E. Review: Continuous hydrolysis and fermentation for cellulosic ethanol production. Bioresour. Technol. 2010, 101, 4862-4874. [CrossRef]

24. Dávila, J.A.; Rosenberg, M.; Cardona, C.A. A biorefinery approach for the production of xylitol, ethanol and polyhydroxybutyrate from brewer's spent grain. AIMS Agric. Food 2016, 1, 52-66. [CrossRef]

25. Ravindran, R.; Jaiswal, S.; Abu-Ghannam, N.; Jaiswal, A.K. A comparative analysis of pretreatment strategies on the properties and hydrolysis of brewers' spent grain. Bioresour. Technol. 2018, 248, 272-279. [CrossRef] [PubMed]

26. Sajib, M.; Falck, P.; Sardari, R.R.R.; Mathew, S.; Grey, C.; Karlsson, E.N.; Adlercreutz, P. Valorization of Brewer's spent grain to prebiotic oligosaccharide: Production, xylanase catalyzed hydrolysis, in-vitro evaluation with probiotic strains and in a batch human fecal fermentation model. J. Biotechnol. 2018, 268, 61-70. [CrossRef] [PubMed]

27. González-García, S.; Morales, P.C.; Gullón, B. Estimating the environmental impacts of a brewery waste-based biorefinery: Bio-ethanol and xylooligosaccharides joint production case study. Ind. Crops Prod. 2018, 123, 331-340. [CrossRef]

28. Lorente, A.; Remón, J.; Budarin, V.L.; Sánchez-Verdú, P.; Moreno, A.; Clark, J.H. Analysis and optimisation of a novel "biobrewery" approach: Production of bio-fuels and bio-chemicals by microwave-assisted, hydrothermal liquefaction of brewers' spent grains. Energy Convers. Manag. 2019, 185, 410-430. [CrossRef]

29. Dehnavi, G.Z.; Laucerica, J.L.; Rodriguez, D.; Beatón, M.; Taherzadeh, M.J.; Martín, C. Fractionation of the main components of barley spent grains from a microbrewery. Cellul. Chem. Technol. 2011, 45, 339-345.

30. Vieira, E.; Rocha, M.A.M.; Coelho, E.; Pinho, O.; Saraiva, J.A.; Ferreira, I.M.P.L.V.O.; Coimbra, M.A. Valuation of brewer's spent grain using a fully recyclable integrated process for extraction of proteins and arabinoxylans. Ind. Crops Prod. 2014, 52, 136-143. [CrossRef]

31. Ravindran, R.; Sarangapani, C.; Jaiswal, S.; Lu, P.; Cullen, P.J.; Bourke, P.; Jaiswal, A.K. Improving enzymatic hydrolysis of brewer spent grain with nonthermal plasma. Bioresour. Technol. 2019, 282, 520-524. [CrossRef]

32. Tang, D.S.; Tian, Y.J.; He, Y.Z.; Li, L.; Hu, S.Q.; Li, B. Optimisation of ultrasonic-assisted protein extraction from brewer's spent grain. Czech. J. Food Sci. 2010, 28, 9-17. [CrossRef]

33. Rommi, K.; Niemi, P.; Kemppainen, K.; Kruus, K. Impact of thermochemical pre-treatment and carbohydrate and protein hydrolyzing enzyme treatment on fractionation of protein and lignin from brewer's spent grain. J. Cereal Sci. 2018, 79, 168-173. [CrossRef]

34. Treimo, J.; Westereng, B.; Horn, S.J.; Forssell, P.; Robertson, J.A.; Faulds, C.B.; Waldron, K.W.; Buchert, J.; Eijsink, V.G.H. Enzymatic solubilization of brewers' spent grain by combined action of carbohydrases and peptidases. J. Agric. Food Chem. 2009, 57, 3316-3324. [CrossRef] [PubMed]

35. Giacobbe, S.; Piscitelli, A.; Raganati, F.; Lettera, V.; Sannia, G.; Marzocchella, A.; Pezzella, C. Butanol production from laccasepretreated brewer's spent grain. Biotechnol. Biofuels 2019, 12, 1-8. [CrossRef] [PubMed]

36. He, Y.; Kuhn, D.D.; Ogejo, J.A.; O’Keefe, S.F.; Fraguas, C.F.; Wiersema, B.D.; Jin, Q.; Yu, D.; Huang, H. Wet fractionation process to produce high protein and high fiber products from brewer's spent grain. Food Bioprod. Process. 2019, 117, 266-274. [CrossRef]

37. Patel, A.; Mikes, F.; Bühler, S.; Matsakas, L. Valorization of brewers' spent grain for the production of lipids by oleaginous yeast. Molecules 2018, 23, 3052. [CrossRef] 
38. Mussatto, S.I.; Moncada, J.; Roberto, I.C.; Cardona, C.A. Techno-economic analysis for brewer's spent grains use on a biorefinery concept: The Brazilian case. Bioresour. Technol. 2013, 148, 302-310. [CrossRef]

39. Bušić, A.; Mardetko, N.; Kundas, S.; Morzak, G.; Belskaya, H.; Šantek, M.I.; Komes, D.; Novak, S.; Šantek, B. Bioethanol production from renewable raw materials and its separation and purification: A review. Food Technol. Biotechnol. 2018, 56, 289-311. [CrossRef] [PubMed]

40. Solarte-Toro, J.C.; Romero-García, J.M.; Susmozas, A.; Ruiz, E.; Castro, E.; Cardona-Alzate, C.A. Techno-economic feasibility of bioethanol production via biorefinery of olive tree prunings (OTP): Optimization of the pretreatment stage. Holzforschung 2019, 73, 3-13. [CrossRef]

41. Rosales-Calderon, O.; Arantes, V. A review on commercial-scale high-value products that can be produced alongside cellulosic ethanol. Biotechnol Biofuels 2019, 12, 240. [CrossRef]

42. Sluiter, A.; Hames, B.; Ruiz, R.; Scarlata, C.; Sluiter, J.; Templeton, D. Determination of Structural Carbohydrates and Lignin in Biomass; Technical Report NREL/TP-510-42618; National Renewable Energy Laboratory: Golden, CO, USA, 2012; pp. 1-15.

43. Fehér, C.; Gazsó, Z.; Tatijarern, P.; Molnár, M.; Barta, Z.; Réczey, K. Investigation of selective arabinose release from corn fibre by acid hydrolysis under mild conditions. J. Chem. Technol. Biotechnol. 2015, 90, 896-906. [CrossRef]

44. Bedő, S.; Antal, B.; Rozbach, M.; Fehér, A.; Fehér, C. Optimised fractionation of wheat bran for arabinose biopurification and xylitol fermentation by Ogataea zsoltii within a biorefinery process. Ind. Crops Prod. 2019, 139, 111504. [CrossRef]

45. Hames, B.; Scarlata, C.; Sluiter, A. Determination of Protein Content in Biomass; Technical Report NREL/TP-510-42625; National Renewable Energy Laboratory: Golden, CO, USA, 2008; pp. 1-5.

46. Sluiter, A.; Hames, B.; Ruiz, R.; Scarlata, C.; Sluiter, J.; Templeton, D. Determination of Ash in Biomass; Technical Report NREL/TP510-42622; National Renewable Energy Laboratory: Golden, CO, USA, 2008; pp. 1-5.

47. Ontañon, O.M.; Ghio, S.; Marrero Díaz de Villegas, R.; Garrido, M.M.; Talia, P.M.; Fehér, C.; Campos, E. A thermostable GH8 endoglucanase of Enterobacter sp. R1 is suitable for $\beta$-glucan deconstruction. Food Chem. 2019, 298, 124999. [CrossRef]

48. Guo, X.; Cavka, A.; Jönsson, L.J.; Hong, F. Comparison of methods for detoxification of spruce hydrolysate for bacterial cellulose production. Microb. Cell Fact. 2013, 12, 1-14. [CrossRef] [PubMed]

49. Kapdan, I.K.; Kargi, F.; Oztekin, R. Effects of operating parameters on acid hydrolysis of ground wheat starch: Maximization of the sugar yield by statistical experiment design. Starch Staerke 2011, 63, 311-318. [CrossRef]

50. González, G.; López-Santín, J.; Caminal, G.; Solà, C. Dilute acid hydrolysis of wheat straw hemicellulose at moderate temperature: A simplified kinetic model. Biotechnol. Bioeng. 1986, 28, 288-293. [CrossRef]

51. Fehér, C. Novel approaches for biotechnological production and application of L-arabinose. J. Carbohydr. Chem. 2018, 37, 251-284. [CrossRef]

52. $\mathrm{Xu}, \mathrm{J} . ;$ Thomsen, M.H.; Thomsen, A.B. Recovery of arabinan in acetic acid-catalyzed hydrothermal pretreatment on corn stover. Biomass Bioenergy 2009, 33, 1660-1663. [CrossRef]

53. Shibanuma, K.; Nordisk, N. Partial Acid Hydrolysis of Corn Fiber for the Production of L-Arabinose. J. Appl. Glycosci. 1999, 46, 249-256. [CrossRef]

54. Tian, Z.; Chen, J.; Ji, X.; Wang, Q.; Yang, G.; Fatehi, P. Dilute sulfuric acid hydrolysis of Pennisetum (sp.) Hemicellulose. BioResources 2017, 12, 2609-2617. [CrossRef]

55. Martin, C.; Alriksson, B.; Sjöde, A.; Nilvebrant, N.-O.; Jönsson, L.J. Dilute Sulfuric Acid Pretreatment of Agricultural and Agro-Industrial Residues for Ethanol Production. Appl. Biochem. Biotecnol. 2007, 136, 339-352.

56. Lee, H.-J.; Lee, W.-K.; Ryu, Y.-W. L-Arabinose Production from Diluted Sulfuric Acid Hydrolysis of Corn-fiber. KSBB J. 2007, 22, 201-206.

57. Mäki-Arvela, P.; Salmi, T.; Holmbom, B.; Willför, S.; Murzin, D.Y. Synthesis of sugars by hydrolysis of hemicelluloses-A review. Chem. Rev. 2011, 111, 5638-5666. [CrossRef]

58. Qing, Q.; Li, H.; Kumar, R.; Wyman, C. Xylooligosaccharides Production, Quantification, and Characterization in Context of Lignocellulosic Biomass Pretreatment. In Aqueous Pretreatment of Plant Biomass for Biological and Chemical Conversion to Fuels and Chemicals; John Wiley \& Sons Ltd.: Chichester, UK, 2013; pp. 391-415.

59. Wijaya, H.; Sasaki, K.; Kahar, P.; Rahmani, N.; Hermiati, E.; Yopi, Y.; Ogino, C.; Prasetya, B.; Kondo, A. High enzymatic recovery and purification of xylooligosaccharides from empty fruit bunch via nanofiltration. Processes 2020, 8, 619. [CrossRef]

60. Bastos, R.; Coelho, E.; Coimbra, M.A. 8-Arabinoxylans from cereal by-products: Insights into structural features, recovery, and applications. In Sustainable Recovery and Reutilization of Cereal Processing By-Products; Galanakis, C.M., Ed.; Elsevier Ltd.: London, UK, 2018; pp. 227-251.

61. Broekaert, W.F.; Courtin, C.M.; Verbeke, K.; van de Wiele, T.; Verstraete, W.; Delcour, J.A. Prebiotic and other health-related effects of cereal-derived arabinoxylans, arabinoxylan-oligosaccharides, and xylooligosaccharides. Crit. Rev. Food Sci. Nutr. 2011, 51, 178-194. [CrossRef]

62. Xiros, C.; Christakopoulos, P. Enhanced ethanol production from brewer's spent grain by a Fusarium oxysporum consolidated system. Biotechnol. Biofuels 2009, 2, 4. [CrossRef]

63. Fehér, C.; Gazsó, Z.; Gál, B.; Kontra, A.; Barta, Z.; Réczey, K. Integrated Process of Arabinose Biopurification and Xylitol Fermentation Based on the Diverse Action of Candida boidinii. Chem. Biochem. Eng. Q. 2015, 29, 587-597. [CrossRef]

64. Rafiqul, I.S.M.; Sakinah, A.M.M. Processes for the Production of Xylitol-A Review. Food Rev. Int. 2013, 29, 127-156. [CrossRef] 
65. Ioelovich, M.; Morag, E. Study of enzymatic hydrolysis of pretreated biomass at increased solids loading. BioResources 2012, 7, 4672-4682. [CrossRef]

66. Caspeta, L.; Caro-Bermúdez, M.A.; Ponce-Noyola, T.; Martinez, A. Enzymatic hydrolysis at high-solids loadings for the conversion of agave bagasse to fuel ethanol. Appl. Energy 2014, 113, 277-286. [CrossRef]

67. Cheng, M.H.; Kadhum, H.J.; Murthy, G.S.; Dien, B.S.; Singh, V. High solids loading biorefinery for the production of cellulosic sugars from bioenergy sorghum. Bioresour. Technol. 2020, 318, 124051. [CrossRef] [PubMed]

68. Jørgensen, H.; Vibe-Pedersen, J.; Larsen, J.; Felby, C. Liquefaction of lignocellulose at high-solids concentrations. Biotechnol. Bioeng. 2007, 96, 862-870. [CrossRef] [PubMed]

69. Ramachandriya, K.D.; Wilkins, M.; Atiyeh, H.K.; Dunford, N.T.; Hiziroglu, S. Effect of high dry solids loading on enzymatic hydrolysis of acid bisulfite pretreated Eastern redcedar. Bioresour. Technol. 2013, 147, 168-176. [CrossRef] [PubMed]

70. López-Linares, J.C.; Romero, I.; Cara, C.; Ruiz, E.; Moya, M.; Castro, E. Bioethanol production from rapeseed straw at high solids loading with different process configurations. Fuel 2014, 122, 112-118. [CrossRef]

71. Manzanares, P.; Negro, M.J.; Oliva, J.M.; Saéz, F.; Ballesteros, I.; Ballesteros, M.; Cara, C.; Castro, E.; Ruiz, E. Different process configurations for bioethanol production from pretreated olive pruning biomass. J. Chem. Technol. Biotechnol. 2011, 86, 881-887. [CrossRef]

72. Wilkinson, S.; Smart, K.A.; James, S.; Cook, D.J. Maximising high solid loading enzymatic saccharification yield from acidcatalysed hydrothermally-pretreated brewers spent grain. Biofuel Res. J. 2016, 3, 417-429. [CrossRef]

73. Rojas-Chamorro, J.A.; Romero, I.; Ruiz, E.; Cara, C.; Castro, E. Comparison of fermentation strategies for ethanol production from pretreated brewers spent grain. Chem. Eng. Trans. 2017, 61, 637-642.

74. Runquist, D.; Hahn-Hägerdal, B.; Rådström, P. Comparison of heterologous xylose transporters in recombinant Saccharomyces cerevisiae. Biotechnol. Biofuels 2010, 3, 1-7. [CrossRef] [PubMed]

75. Tesfaw, A.; Assefa, F. Current Trends in Bioethanol Production by Saccharomyces cerevisiae: Substrate, Inhibitor Reduction, Growth Variables, Coculture, and Immobilization. Int. Sch. Res. Not. 2014, 2014, 1-11. [CrossRef] [PubMed]

76. Wilkinson, S.; Smart, K.A.; Cook, D.J. Optimisation of alkaline reagent based chemical pre-treatment of Brewers spent grains for bioethanol production. Ind. Crops Prod. 2014, 62, 219-227. [CrossRef]

77. Rojas-Chamorro, J.A.; Romero-García, J.M.; Cara, C.; Romero, I.; Castro, E. Improved ethanol production from the slurry of pretreated brewers' spent grain through different co-fermentation strategies. Bioresour. Technol. 2019, 296, 122367. [CrossRef] [PubMed]

78. White, J.S.; Yohannan, B.K.; Walker, G.M. Bioconversion of brewer's spent grains to bioethanol. FEMS Yeast Res. 2008, 8, 1175-1184. [CrossRef] [PubMed] 